\title{
Transcriptomic analysis of human placenta in intrauterine growth restriction
}

Doriane Madeleneau ${ }^{1-4}$, Christophe Buffat ${ }^{5}$, Françoise Mondon ${ }^{1-3}$, Hélène Grimault ${ }^{1-3,6}$, Virginie Rigourd ${ }^{1-3,7}$, Vassilis Tsatsaris ${ }^{8}$, Franck Letourneur ${ }^{1-3}$, Daniel Vaiman ${ }^{1-3}$, Sandrine Barbaux ${ }^{1-3}$ and Géraldine Gascoin ${ }^{1-3,6}$

BACKGROUND: Intrauterine growth restriction (IUGR) is a frequent complication of pregnancy defined as a restriction of fetal growth. The objective of this work was to improve the knowledge on the pathophysiology of IUGR using a genomewide method of expression analysis.

METHODS:Weanalyzed differentially expressed genes in pooled placental tissues from vascular IUGR (four pools of three placentas) and normal pregnancies (four pools of three placentas) using a long nucleotide microarray platform (Nimblegen). We first did a global bioinformatics analysis based only on $P$ value without any a priori. We secondly focused on "target" genes among the most modified ones. Finally, reverse transcription quantitative polymerase chain reaction (RT-qPCR) was performed on an extended panel of tissue samples ( $n=62$ ) on selected "target".

RESULTS: We identified 636 modified genes among which 206 were upregulated $(1.5$ and higher; $P<0.05)$. Groups of patients were classified unambiguously. Genes involved in mitochondrial function and oxidative phosphorylation were decreased affecting three out of five complexes of the respiratory chain of the mitochondria, and thus energy production and metabolism. Among the most induced genes, we identified $L E P$, IGFBPI, and RBP4.

CONCLUSION: Complementary studies on the role and function of $L E P$, IGFBP1, and RBP4 in IUGR pathophysiology and also in fetal programming remain necessary.

ntrauterine growth restriction (IUGR) is a frequent complication of pregnancy with a prevalence of $8 \%$ in the general population. It is defined as a restriction of fetal growth during pregnancy, "a foetus that doesn't reach its growth potential". It can lead to a birth weight and/or length below the 10th percentile for a given gestational age in new-borns thus considered as "Small for Gestational Age" $(1,2)$. IUGR represents a major public health problem, being one of the main causes of prematurity, perinatal mortality, neurological, and respiratory morbidities (3-6). It is also suspected to be a determining factor in the development of cardiovascular diseases, obesity, and type 2 diabetes later in adulthood (7-9).
Fetal growth is inseparable from placental growth and requires a nutrient supply both continuous and adapted to each pregnancy period, as documented by animal model analysis (10). Several microarray studies have analyzed the transcriptome of pre-eclamptic (associated or not to IUGR) placentas to identify genes that could be involved in placental dysfunction. In general, similar categories of differentially expressed genes were reported including genes involved in vascular regulation, inflammation, cell proliferation, apoptosis, differentiation, and cellular metabolism. However, in some cases, the results appeared controversial. These differences may be due to the type of IUGR, the sampling of placentas, gestational age, ethnicity, the mode of delivery, microarray platforms, and the filtering and statistical analysis. Recently, two meta-analyses of placental gene expression patterns in preeclampsia case/control studies have been reported, identifying consistently modified genes and biological pathways such as cell responses to inflammation, hypoxia, DNA damage, and proliferation $(11,12)$. Up to recently, none of such analyses had been reported focusing on IUGR. The objective of this work was to compare the global expression profile of human placentas obtained after Caesarean section from pregnancies close to term complicated or not by vascular IUGR.

\section{RESULTS}

The average term of the IUGR population was $33.8 \mathrm{wk}$ of gestation vs. 38.7 in the control group, with an average weight of $1,418 \mathrm{~g}$ vs. $3,320 \mathrm{~g}$ and a sex ratio of $1: 1$ in the IUGR population and 5:1 in the control group (Table 1). The index of RNA integrity (RIN) obtained for each pool ranged between 7.2 and 8.1 .

\section{Global Analysis Based on $P$ Value}

We have decided to first present a global analysis based only on $P$ value without any a priori with Array Mining software (School of Computer Science, Nottingham University, UK). The 500 most significant genes according to their increasing $P$ value are presented in greater detail in Supplementary Table S1 online. Boxplots for expression values of the four top-ranked 


\section{Articles $\mid$ Madeleneau et al.}

genes (STAG3L2, PRKACA, INO80D, SZT2 respectively) were done with a very good segregation between IUGR and control placenta samples (Figure 1). A heatmap (nonsupervised clustering) classifying the 500 genes selected through increasing significance classified the groups of patients unambiguously as presented in Supplementary Figure S1 online and in Figure 2 for the 100 most significant ones. In terms of gene ontology, starting from the 500 most modified genes, significant enriched

Table 1. Baseline characteristics of the mothers and newborns from whom placental samples were obtained for the microarray analysis

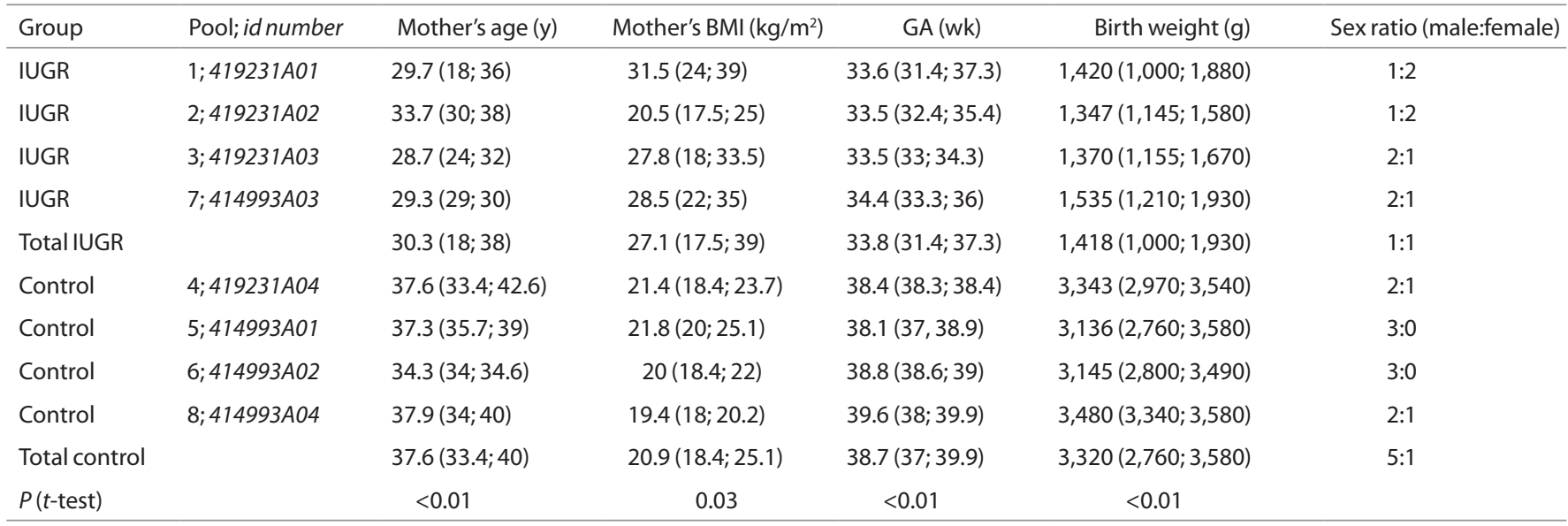

Data presented as average (min; max).
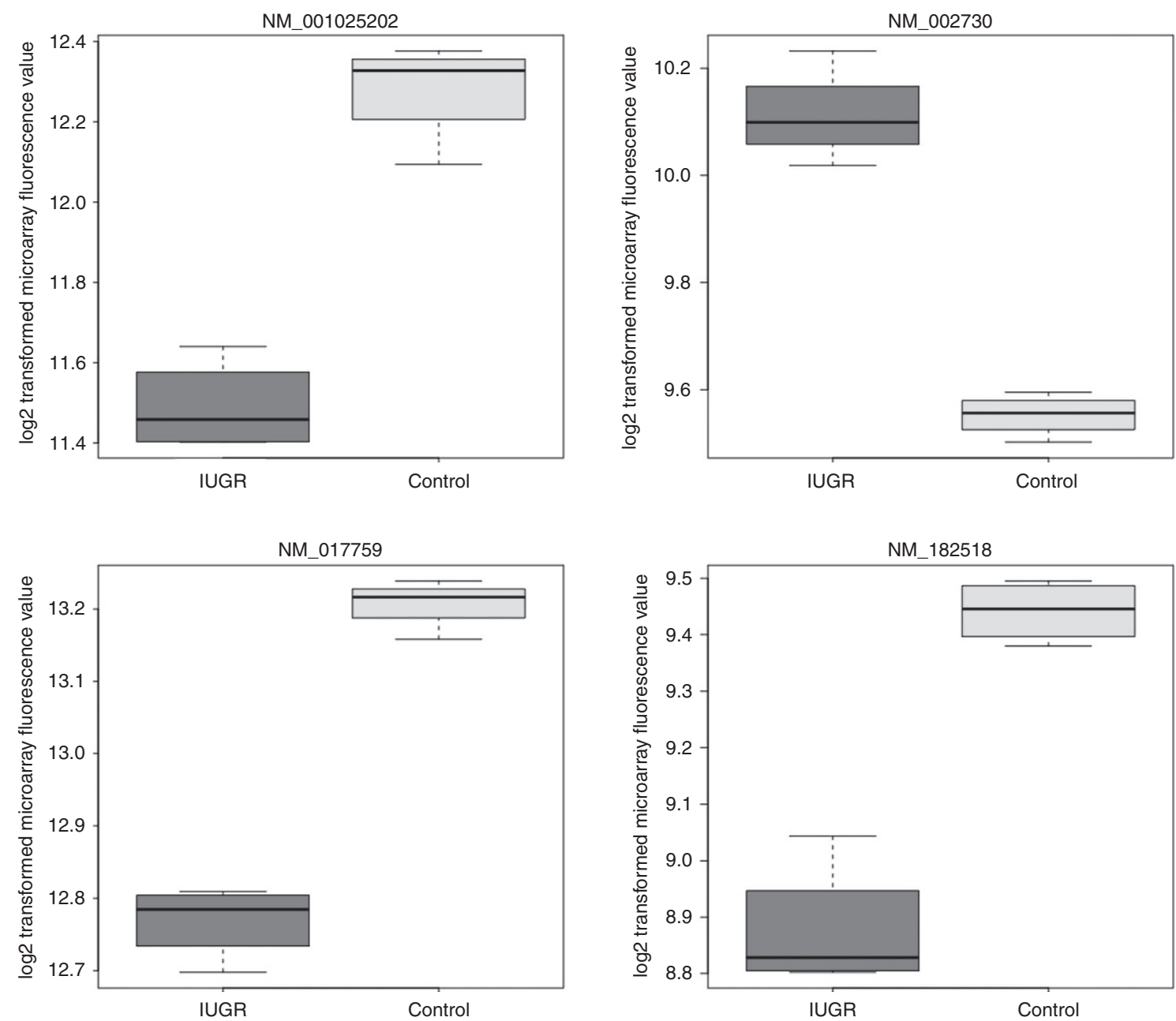

Figure 1. Boxplots top ranked genes $(n=4)$ selected according to their $P$ value, with a very good segregation between intrauterine growth restriction and control placenta samples. Y-axis represents $\log 2$ transformed microarray fluorescence value. 
KEGG pathways could be identified, several between them closely related to lipid metabolism (fatty acid metabolism, PPAR pathway, adipocytokine signaling pathway) (Table 2). Boxplots of enriched pathways $(n=4)$ were done with a very good segregation between IUGR and control placenta samples (Figure 3). A complementary analysis by DAVID, focusing on repressed genes identified 227 downregulated transcripts and the KEGG analysis reveals downregulation of a series of genes involved in cell division, and MAP kinase signaling pathways (anaphase promoting complex (APC/C), $\beta$-transudicne repeat $(\beta-T R c P)$, cyclin B1, PKC $\alpha)$. However, the decreased expression of these genes is mild $(-20$ to $-30 \%)$. Similarly, genes involved in mitochondrial function and oxidative phosphorylation were decreased (NADH dehydrogenase, cytochrome $\mathrm{C}$ oxidase Va, ubiquinol-cytochrome $\mathrm{C}$ reductase), thus able to affect three out of five complexes of the respiratory chain of the

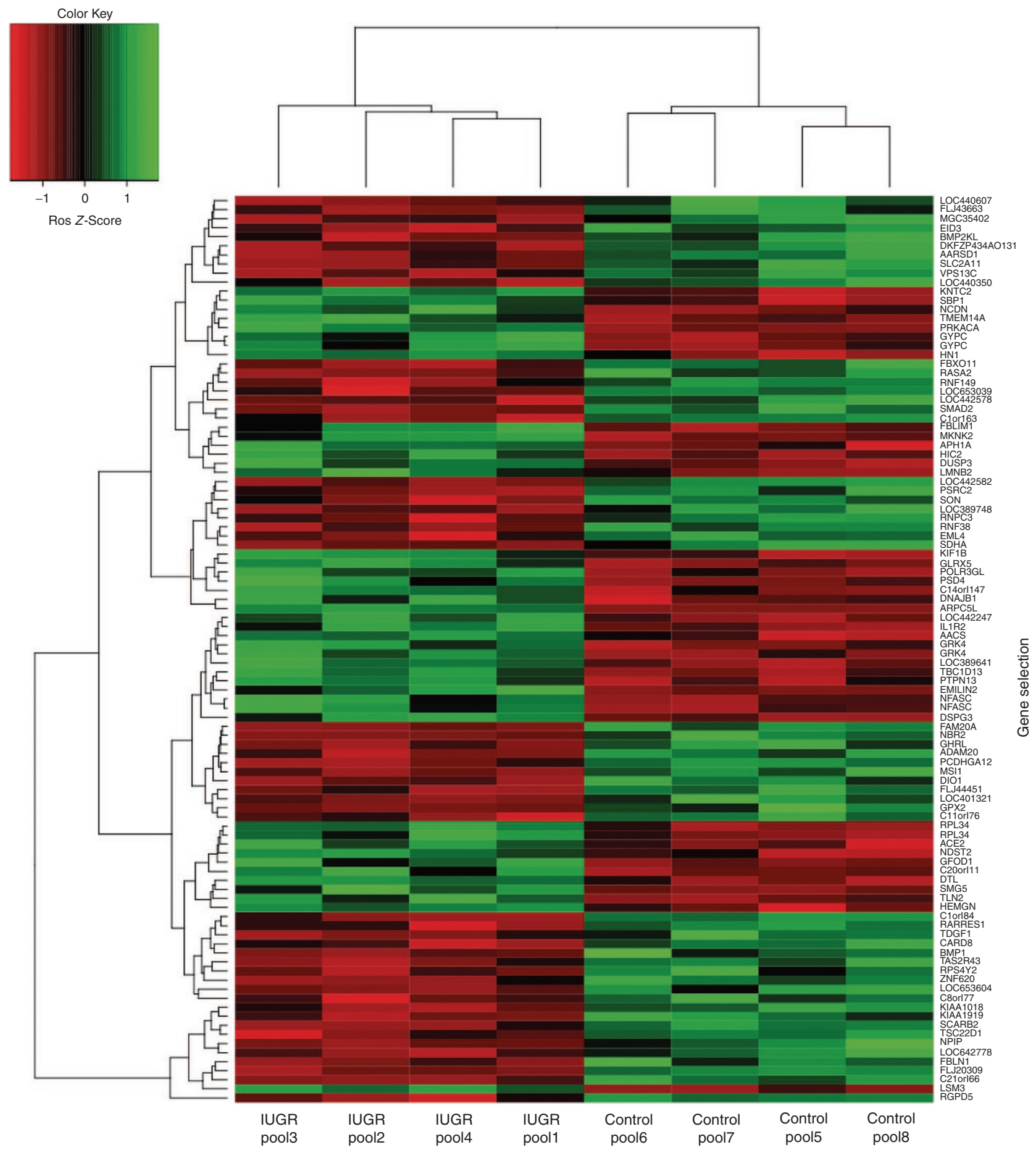

Figure 2. Heatmap representation of the 100 most significant genes selected through their increasing $P$ value. Each measurement represents the normalized ratio of fluorescence from the hybridized experimental material to a common internal reference (intrauterine growth restriction and control). 
Table 2. Pathways analysis: according to significant enriched KEGG pathways and according to gene ontology (Array Mining Software)

\begin{tabular}{|c|c|c|c|}
\hline Pathway name (KEGG) & $\begin{array}{l}\text { PC (meta-gene } \\
\text { vs. outcome) }\end{array}$ & Q-values & $\begin{array}{l}\text { Median fold } \\
\text { change }\end{array}$ \\
\hline 04742 Taste transduction & -0.81 & 0.28 & 1.14 \\
\hline 00310 Lysine degradation & 0.87 & 0.28 & 1.19 \\
\hline $\begin{array}{l}05130 \text { Pathogenic } \\
\text { Escherichia coli infection- } \\
\text { Enterohaemorrhagic E. coli }\end{array}$ & 0.81 & 0.57 & 1.05 \\
\hline $\begin{array}{l}05131 \text { Pathogenic } \\
\text { Escherichia coli infection- } \\
\text { Enteropathogenic E. coli }\end{array}$ & 0.81 & 0.57 & 1.05 \\
\hline $\begin{array}{l}04920 \text { Adipocytokine } \\
\text { signaling pathway }\end{array}$ & 0.7 & 0.59 & 1.22 \\
\hline 00071 Fatty acid metabolism & 0.8 & 0.59 & 1.11 \\
\hline 00512 O-Glycan biosynthesis & 0.77 & 0.66 & 1.14 \\
\hline $\begin{array}{l}04120 \text { Ubiquitin mediated } \\
\text { proteolysis }\end{array}$ & 0.81 & 0.66 & 1.03 \\
\hline $\begin{array}{l}00562 \text { Inositol phosphate } \\
\text { metabolism }\end{array}$ & 0.73 & 0.66 & 1.16 \\
\hline $\begin{array}{l}\text { 03320 PPAR signaling } \\
\text { pathway }\end{array}$ & 0.78 & 0.71 & 1.14 \\
\hline $\begin{array}{l}\text { Pathway name } \\
\text { (gene ontology) }\end{array}$ & $\begin{array}{l}\text { PC (meta-gene } \\
\text { vs. outcome) }\end{array}$ & Q-values & $\begin{array}{l}\text { median } \\
\text { fold change }\end{array}$ \\
\hline $\begin{array}{l}\text { GO:0044433 cytoplasmic } \\
\text { vesicle part }\end{array}$ & 0.85 & 0.79 & 1.1 \\
\hline $\begin{array}{l}\text { GO:0006814 sodium ion } \\
\text { transport }\end{array}$ & -0.91 & 0.79 & 15.31 \\
\hline $\begin{array}{l}\text { GO:0010564 regulation of cell } \\
\text { cycle process }\end{array}$ & 0.83 & 0.79 & 15.31 \\
\hline $\begin{array}{l}\text { GO:0001558 regulation of cell } \\
\text { growth }\end{array}$ & 0.74 & 0.79 & 1.13 \\
\hline $\begin{array}{l}\text { GO:0048015 } \\
\text { phosphoinositide-mediated } \\
\text { signaling }\end{array}$ & 0.71 & 0.79 & 15.31 \\
\hline $\begin{array}{l}\text { GO:0019748 secondary } \\
\text { metabolic process }\end{array}$ & 0.7 & 0.79 & 3.45 \\
\hline $\begin{array}{l}\text { GO:0031402 sodium ion } \\
\text { binding }\end{array}$ & -0.82 & 0.79 & 15.31 \\
\hline $\begin{array}{l}\text { GO:0051258 protein } \\
\text { polymerization }\end{array}$ & 0.77 & 0.79 & 1.08 \\
\hline $\begin{array}{l}\text { GO:0000075 cell cycle } \\
\text { checkpoint }\end{array}$ & 0.79 & 0.79 & 1.39 \\
\hline $\begin{array}{l}\text { GO:0031968 organelle outer } \\
\text { membrane }\end{array}$ & 0.78 & 0.79 & 1.08 \\
\hline
\end{tabular}

Q-values, the minimum false discovery rate at which the test may be called significant. PC, Pearson correlation.

mitochondria, and affect energy production and metabolism. The downregulation, while significant in terms of statistics is mild ( -25 to $-30 \%)$, which may nevertheless have a biological effect.

The same analysis on the part of significantly induced genes in the list of 500 identified, allowed to identify 157 transcripts, among which the most important category grouped genes involved in mRNA metabolism, processing, and transport. Among these 157 genes, 11 are involved in RNA binding with induction ratios from 1.17 to 2.28 (Table 3 ).
Target Approach Based on the Ratio of Expression

The array analysis allowed detecting 23,456 transcripts, among which only 636 were differentially expressed at a threshold of $1.5(P<0.05)$ in placentas with IUGR, representing $2.7 \%$ of the whole transcripts tested, among which 206 were induced and 430 repressed.

The 500 most significant genes according to their $P$ value are different from the one selected only on the ratio of expression. Indeed, 3,667 transcripts among the 23,456 detected have a $P$ value below 0.05 . Nevertheless, we found a good correlation between individual genes and pathways when we focused on the first 2,000 most significant genes according to their $P$ value or to their ratio of expression.

Among the most induced genes in IUGR, we identified LEP (leptin) (3.5-fold), IGFBP1 (insulin-like growth factor binding protein 1) (3.4-fold) and SERPIN A3 (2-fold) (Table 4).

The bioinformatic analysis of signaling pathways by clustering on the most modified genes in IUGR revealed gene clusters involved in growth control, response to insulin, hormonal regulation with a cluster encompassing IGFBP1-LEP-RBP4 (retinol-binding protein 4)-ceruloplasmin-chemokine-complement factor $\mathrm{H}$ related 1 -fibrinogen $\gamma$-chain (enrichment score 1.31).

The promoters of the most modified genes ( $n=40$ induced and $n=40$ repressed genes) were compared to a panel of 40 random nonmodified genes with the Genomatix software. It highlighted a significant increase $(P<0.01)$ in the frequency of potential binding sites for known transcription factors including CTCF (CCCTC-binding factor), which belongs to the Zinc Finger protein family.

\section{Validation of Microarray Data}

qRT-PCR on an extended panel of normal placentas $(n=21)$, placentas with IUGR $(n=26)$, with pre-eclampsia $(n=9)$, with pre-eclampsia and IUGR $(n=6)$ successfully validated the microarray data for a selection of deregulated genes: $L E P$, $I G F B P 1$, and RBP4 (Table 5; Figure 4). The expression level of each gene was also analyzed according to the sex of the fetus. We confirmed a highly significant increase in the expression of these three genes in IUGR placentas. We compared the present data with that obtained from the recent study by Nishizawa et al. (13), with a particular interest in the most modified genes in our data $(n=636)$ (publicly available on GEO profiles http://www.ncbi.nlm.nih.gov.gate2.inist.fr/geoprofiles). The two data sets were found to be strongly correlated $(r=0.41$; $n=353 ; P<0.001)$ and a list of 13 common genes were shown to be similarly and significantly affected (Table 6).

Surprisingly, among the 13 commonly modified genes, 5 genes were located on the $\mathrm{Y}$ chromosome and significantly repressed. Among the genes from the $\mathrm{Y}$ chromosome that were significantly different in IUGR placentas (ratio $<0.67$ and $>1.5$ ) in our study, 12 genes were repressed while only one was induced, a very significant bias toward repression $\left(P<9 \times 10^{-17}\right)$. We had the same observation when we focused our statistical analysis only on the pool with the same sex-ratio 2:1 male:female (IUGR pool 3 and 7; control pool 4 and 8). 

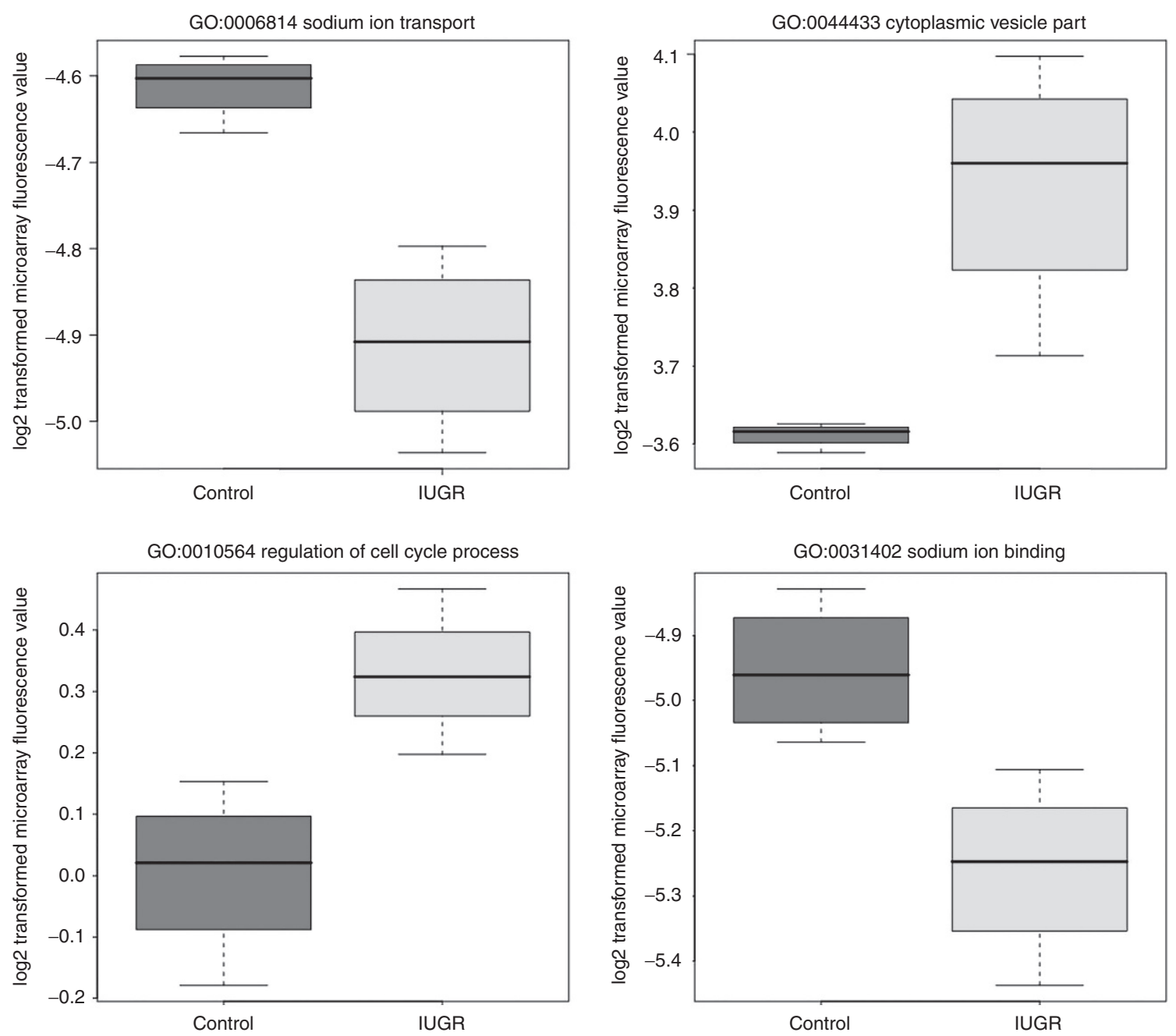

Figure 3. Boxplots of enriched pathways $(n=4)$ were done with a very good segregation between intrauterine growth restriction and control placenta samples. Y-axis represents $\log 2$ transformed microarray fluorescence value.

Table 3. Significantly induced genes involved in RNA binding in the list of the 500 most modified genes according to $P$ value

\begin{tabular}{llc}
\hline Genbank_Accession & \multicolumn{1}{c}{ Gene name } & Induction ratio \\
\hline NM_004640 & HLA-B associated transcript 1 & 1.33 \\
NM_017619 & $\begin{array}{l}\text { RNA-binding region (RNP1, RRM) } \\
\text { containing 3 }\end{array}$ & 1.43 \\
NM_032195 & $\begin{array}{l}\text { SON DNA binding protein } \\
\text { NM_022037 }\end{array}$ & 1.80 \\
& $\begin{array}{l}\text { TIA1 cytotoxic granule- } \\
\text { associated RNA binding protein }\end{array}$ & 1.46 \\
NM_001033506 & $\begin{array}{l}\text { Cleavage stimulation factor, 3' } \\
\text { pre-RNA, subunit 3, 77kDa }\end{array}$ & 1.87 \\
NM_001889 & $\begin{array}{l}\text { Crystallin, zeta (quinone } \\
\text { reductase) }\end{array}$ & 1.49 \\
NM_003902 & $\begin{array}{l}\text { Far upstream element binding } \\
\text { protein 1 }\end{array}$ & 1.51 \\
NM_002024 & Fragile X mental retardation 1 & 1.17 \\
NM_002442 & Musashi homolog 1 (Drosophila) & 1.38 \\
NM_001039567 & Ribosomal protein S4, Y-linked 2 & 2.28 \\
NM_007185 & \begin{tabular}{l} 
Trinucleotide repeat containing 4 \\
\hline
\end{tabular} & 1.59 \\
\hline
\end{tabular}

In addition, there was a very strong correlation between the repression ratio $(<0.67)$ and the position of the genes along the Y chromosome $(r=0.75 ; n=12 ; P=0.002)$.

\section{DISCUSSION}

We analyzed differentially expressed genes in pooled placental tissues from vascular IUGR and normal pregnancies (four pools of 3 placentas each) using a microarray method. We identified 636 modified genes among which 206 were upregulated.

One limitation of our study was the difference in gestational ages, even if the IUGR new-borns population is a mild preterm one. But, matching gestational control placentas would have been premature ones and thus exposed to RNA variations due to other causes of premature births (such as preterm labor, preterm rupture of membranes, chorioamniotisis and so on). Moreover, the nonspecific transcriptional variations that could occur between placentas from different gestational ages, is mainly described in extreme gestational ages (13). We also only used placentas collected after Caesarean sections to avoid the putative alterations in gene expression induced by labor. The inclusion of vascular IUGR placentas permits the study 


\section{Articles $\mid$ Madeleneau et al.}

Table 4. Most modified genes according to ratio of expression

\begin{tabular}{|c|c|c|c|c|c|}
\hline \multicolumn{3}{|c|}{ Ten most induced genes } & \multicolumn{3}{|c|}{ Ten most repressed genes } \\
\hline Gene name & Genbank_Accession & Induction ratio & Gene name & Genbank_Accession & Induction ratio \\
\hline S100A14 & NM_020672 & 4.31 & C8orf79 & NM_182598 & 0.45 \\
\hline $\mid G F B P 1$ & NM_001013029 & 3.41 & ANP32D & NM_012404 & 0.45 \\
\hline RBP4 & NM_006744 & 3.34 & BEX1 & NM_018476 & 0.45 \\
\hline $\mid G F B P 1$ & NM_000596 & 2.97 & TARP & NM_001003799 & 0.43 \\
\hline FGG & NM_021870 & 2.93 & FBXO32 & NM_148177 & 0.42 \\
\hline$V C Y$ & NM_004679 & 2.83 & OR51B5 & NM_001005567 & 0.39 \\
\hline TREM1 & NM_018643 & 2.68 & PPIAL4 & NM_178230 & 0.37 \\
\hline KRTHA4 & NM_021013 & 2.66 & OR51B4 & NM_033179 & 0.28 \\
\hline
\end{tabular}

Ratios associated with a probability based on a Student's test, $P<0.05$.

Table 5. Baseline characteristics of the mothers and newborns from whom placental samples were obtained for reverse transcription quantitative polymerase chain reaction

\begin{tabular}{|c|c|c|c|}
\hline Total $(n=62)$ & $\begin{array}{l}\text { Gestational } \\
\text { age (weeks) }\end{array}$ & Birth weight (g) & $\begin{array}{l}\text { Sex ratio } \\
\text { (male:female) }\end{array}$ \\
\hline Control $(n=21)$ & $38.9(38 ; 40.3)$ & $3,506(3,030 ; 4,430)$ & 9:12 \\
\hline IUGR $(n=26)$ & $34.4(28.8 ; 38)$ & $1,487(700 ; 2,330)$ & $13: 13$ \\
\hline $\operatorname{PE}(n=9)$ & $32(29.7 ; 34.3)$ & $1,557(1,070 ; 1,960)$ & $3: 6$ \\
\hline IUGR + PE $(n=6)$ & $33.2(28.7 ; 38.4)$ & $1,485(830 ; 2,400)$ & 2:4 \\
\hline
\end{tabular}

Data presented as average (min; max).

$P E$, pre-eclampsia.

of a more reliable and homogeneous population. While pooling of samples for microarray experiments might be considered as a limitation of this study, we successfully validated the most significant data on individual placentas and on a larger panel of samples from all groups. Furthermore, we were able to find some common transcriptional changes with two similar recent reports $(14,15)$, which studied populations of similar gestational age and using the similar method of placenta collection after Caesarean section. The small number of significantly modified genes, 252 found by Nishizawa et al. (14) and 241 found by Struwe et al. (15), may be due to the disease by itself that is heterogeneous in nature. The heterogeneity in cell types within the placenta can also affect the signal-to-noise ratio in the identification of modified genes (16). We have only suggestive elements and no strong evidence of downregulation of Y-linked genes in IUGR placenta and the sex ratio to 1:5 male:female in the control group may constitute a limitation in our observation.

\section{Signaling Pathways}

In IUGR, pathways encompassing genes involved in cell cycle are enriched. By all means, there is an impact on these cascades, whatever the sense. It is also possible that the effect is overall very small when opposite mechanisms attempt to compensate the IUGR effects in terms of shortage of nutrients for instance.

Genes involved in mitochondrial function and oxidative phosphorylation were decreased affecting three out of five complexes of the respiratory chain of the mitochondria, and thus energy production and metabolism. Recent studies done on placentas from pregnancies with IUGR and/or preeclampsia suggested modifications on placental mitochondrial content and function that could be important in the genesis of pre-eclampsia or IUGR $(17,18)$. Lower mRNA levels of complex II, III, and IV were found in IUGR cytotrophoblast cells but no differences at the protein level (18). Finally, cytotrophoblast respiratory chain complexes activity was significantly increased in placentas of IUGR fetuses (18). Nevertheless, increased placental oxygen consumption might represent a limiting step in fetal growth restriction, preventing adequate oxygen delivery to the fetus.

RNA metabolism alterations in IUGR were already seen in the placenta in one of our previous works in the rat model where IUGR was triggered by maternal protein restriction during pregnancy (10). It was especially apparent in induced gene clusters, where SWI/SNIF, subunits of the DNA polymerase and splice factors were duly modified, and may suggest a general involvement in adaption to IUGR either experimentally induced in animal models or in humans. While the data about this aspect are relatively scarce, it would be an interesting trail to follow to understand the consequences of IUGR. In some rare human syndromes including growth retardation among the symptoms (Taybi-Linder syndrome), mutations in elements of the RNA splicing complex (U4atac snRNA) were indeed discovered (19).

\section{Target Genes}

Among the genes most highly induced by IUGR, we observed inductions in LEP (3.5-fold), also found by Nishizawa and Struwe, IGFBP1 (3.4-fold) and RBP4 (3.3-fold) as also found by Struwe.

Placental leptin is produced by syncytiotrophoblasts and has both autocrine and paracrine actions. It is exported to both maternal and fetal circulations, affecting maternal (fertility and energetic metabolism), placental (angiogenesis, growth, and immune tolerance), and fetal functions (implantation, development, and growth) (20-22). A deregulation of leptin 


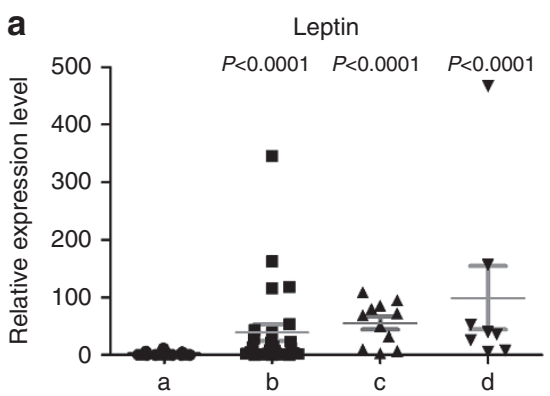

b
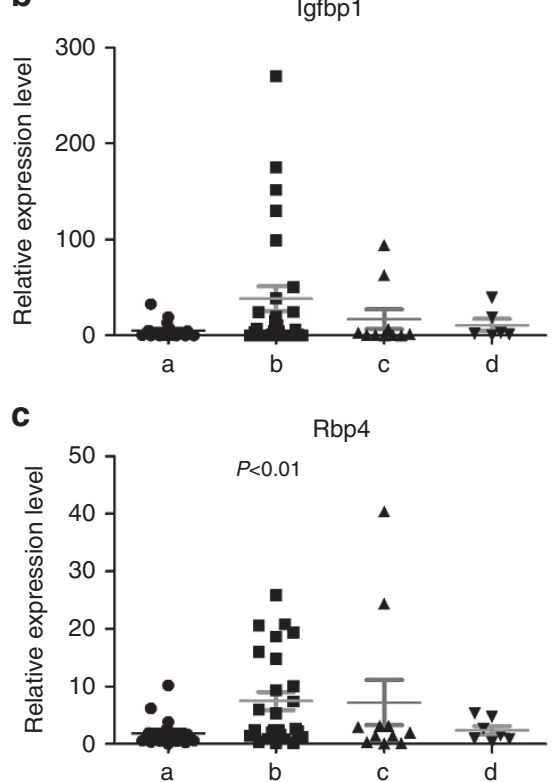
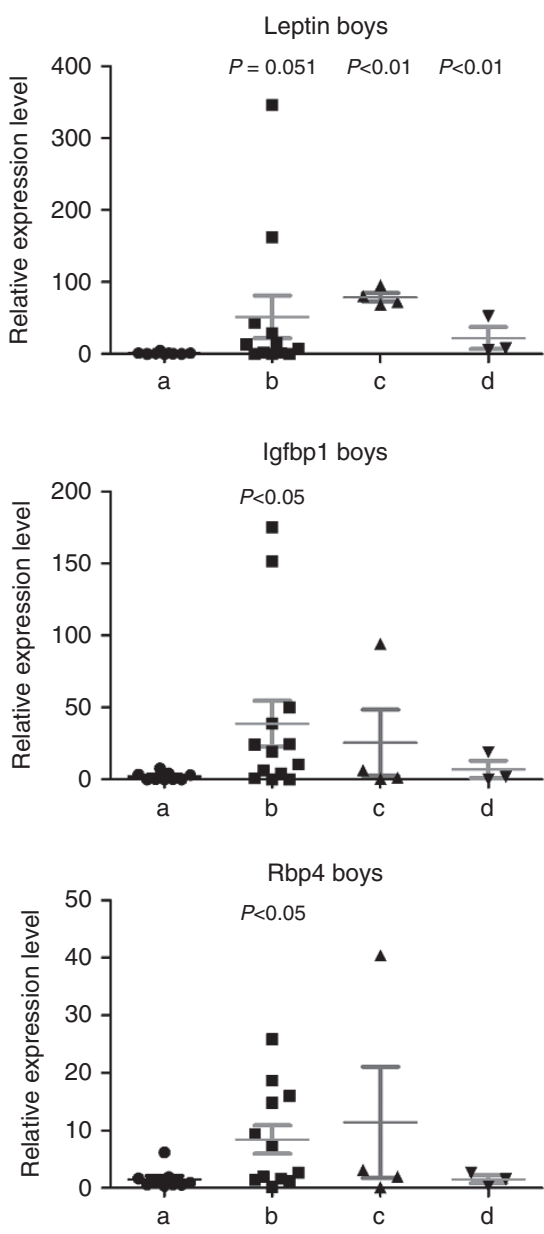

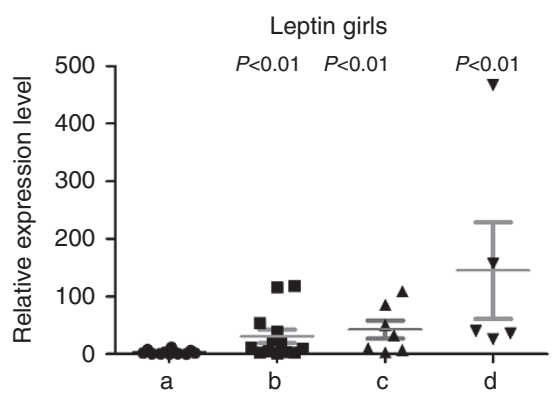

lgfbp1 girls

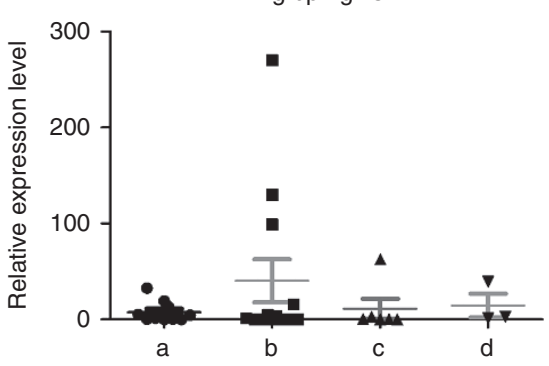

Rbp4 girls

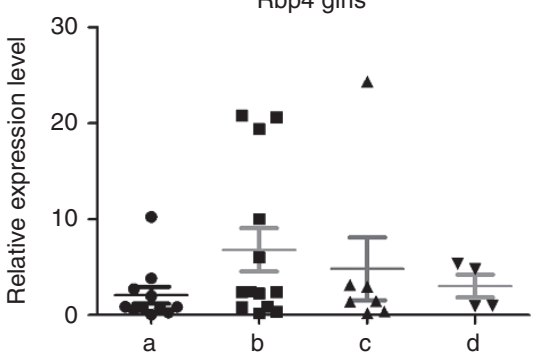

Figure 4. Expression of the LEP (a), IGFBP1 (b), and RBP4 (c) genes in normal and pathological placentas and stratified according to the sex of the fetus by real-time quantitative RT-PCR. Expression levels were normalized to succinate dehydrogenase subunit A and TATA box binding protein as housekeeping genes. Data are presented as mean \pm SEM and the expression in pathological placentas (intrauterine growth restriction (IUGR) (b, black squares) $(n=26)$; pre-eclampsia (PE) (c, black triangles) $(n=9)$; IUGR + PE (d, black upside-down triangles) $(n=6))$ were presented as ratios relative to the control group (a, black circles) $(n=21)$.

Table 6. List of genes similarly and significantly affected in previous transcriptomic study

\begin{tabular}{lccc}
\hline Gene name & Genbank_Accession & Induction ratio & $\begin{array}{c}\text { Induction } \\
\text { ratio (14) }\end{array}$ \\
\hline LEP & NM_000230 & 3.48 & 2.78 \\
CXCL9 & NM_002416 & 2.40 & 1.81 \\
HTRA4 & NM_153692 & 1.94 & 1.81 \\
FSTL3 & NM_005860 & 1.93 & 1.67 \\
NNAT & NM_005386 & 1.78 & 1.78 \\
HIST1H1T & NM_005323 & 0.65 & 0.63 \\
PCDH11X & NM_032967 & 0.63 & 0.62 \\
GABRE & NM_004961 & 0.63 & 0.58 \\
RPS4Y1 & NM_001008 & 0.61 & 0.61 \\
USP9Y & NM_004654 & 0.61 & 0.55 \\
DDX3Y & NM_004660 & 0.55 & 0.51 \\
EIF1AY & NM_004681 & 0.54 & 0.66 \\
UTY & NM_182660 & 0.51 & 0.58 \\
\hline
\end{tabular}

Ratios associated with a probability based on a Student's test, $P<0.05$. metabolism and/or function in the placenta is suspected in some pregnancy pathologies including recurrent fetal loss, gestational diabetes, IUGR, and pre-eclampsia, and is associated with growth defects and metabolic anomalies (23-25). In addition, resistance to leptin is a physiopathological mechanism implicated in obesity (26).

IGFBP1 has a high affinity for both insulin-like growth factor (IGF) 1 and IGF2, which are important fetal and placental growth factors (27). An increase in IGFBP1 expression could inhibit IGF function in the fetoplacental unit. The placental expression of IGFBP 1 is negatively correlated to both placental weight and birth weight (18). In addition, IGFBP1 acts as an antiapoptotic factor in fetal liver cells (28). In the placenta, it could protect the fetoplacental unit from an excess of apoptosis secondary to placental insufficiency. Moreover, IGFBP1 has recently been shown to be a marker of insulin resistance and obesity (29).

The RBP4 gene, coding for a retinoic acid transporter, has also been identified in other studies as modified in IUGR. It has been shown that the umbilical serum concentration of RBP4 was correlated with the child's birth weight (30). The circulating level of RBP4 has been shown to be increased in a 


\section{Articles Madeleneau et al.}

rat model IUGR and later development of obesity. This level is normalized by physical exercise (31). A high level of RBP4 is also associated with an increased incidence of glucose intolerance, obesity, and arterial hypertension $(32,33)$.

$L E P, I G F B P 1$, and RBP4 overexpression therefore provide a good rationale for both the development of IUGR and also the potential progression toward a metabolic syndrome in adults that were growth restricted in utero.

\section{Conclusion}

LEP, IGFBP1, and RBP4 are good candidates to play a role in the origin of IUGR as well as to predict the potential development toward a metabolic syndrome in adults that were growth restricted in utero (IUGR). Complementary studies on the role and function of these genes in IUGR pathophysiology and also in fetal programming of cardiovascular pathologies, obesity, and glucose intolerance in adulthood remain necessary.

\section{METHODS}

\section{Ethical Issues and Patients}

All placentas were collected from two maternity wards (Hôpital Cochin and Institut de Puériculture, Paris, France). This study was approved by the Ethics Committee and CCPPRB (Comité Consultatif de Protection des Personnes dans la Recherche Biomédicale) of Paris Cochin. All patients gave their written consent for the use of their placenta and blood samples. Placentas of 30 or more weeks of gestation were obtained from Caesarean sections before onset of labor. For the microarray analysis, patients were classified in two groups: isolated vascular IUGR $(n=12)$ and control group $(n=12)$. Vascular IUGR was defined by a reduction of fetal growth during gestation, with a notch observed by Echo-Doppler in at least one uterine artery and with Doppler abnormalities on ombilical Doppler and/or cerebral Doppler and/or ductus venosus, and with a birth weight below the 10th percentile according to Audipog growth curves (34). Vascular IUGR was confirmed by the anatomopathological analysis of the placenta after birth. Women who exhibited any of the following criteria were excluded from the study: diabetes, pre-eclampsia, chromosomal and fetal malformations, maternal infections, aspirin treatment, and addictions (such as tobacco or drug usage). In addition, an extended and separate panel of control, vascular IUGR and/or pre-eclamptic placentas was used for further validation studies $(n=62)$. The inclusion criteria used for pre-eclampsia were systolic pressure above 140 $\mathrm{mmHg}$, diastolic pressure above $90 \mathrm{mmHg}$ and proteinuria above $0.3 \mathrm{~g}$ per day. Women who underwent Caesarean section without disease during pregnancy formed the control group.

\section{Placental Biopsy Collection}

All IUGR and control placental biopsies were obtained following Caesarean sections to avoid any effects of labor upon gene expression. To avoid RNA degradation, only placental tissues dissected less than $30 \mathrm{~min}$ after delivery were included. After removal of maternal deciduas and amniotic membranes, sections of $1 \mathrm{~cm}^{3}$ of placental villi were dissected from four different cotyledons between the basal and chorionic plates, as previously described $(35,36)$. After vigorous washing with saline solution $(0.9 \%)$ to remove maternal blood, tissues were immediately immersed in Trizol ( $5 \mathrm{ml} / \mathrm{g}$, Invitrogen, Carlsbad, CA) and stored at $-80{ }^{\circ} \mathrm{C}$ until use. Placenta samples obtained from different areas of a single placenta were pooled before RNA extraction.

\section{RNA Preparation, cDNA Synthesis, and Microarray Hybridizations}

RNA isolation of 12 control and 12 IUGR placenta samples was performed according to standard protocols using Trizol reagent and samples were quantitatively and qualitatively controlled (37). Three individual placenta samples within a group were then pooled, to produce four pools of vascular IUGR and four pools of normal pregnancy for the control group. The eight pools were then evaluated for purity, integrity, and quantification by the Agilent Bioanalyser $2100^{\mathrm{R}}$. One microgram total RNA from each pool was reverse transcribed, labeled, and then hybridized to NimbleGen Human HG18 60 mer $4 x 72 \mathrm{~K}$ arrays representing 23,456 human transcripts. Image analysis was performed with the NimbleScan software (Roche NimbleGen, Madison, WI), and feature intensities were exported as pair files. ArrayStar $3.0^{\mathrm{R}}$ software (DNASTAR, Madison, WI) was used for probe summarization and normalization (RMA algorithm, quantile normalization), statistical analysis of differentially expressed genes (Student's $t$-test with Benjamini-Hochberg false discovery rate correction), and gene ontology analysis. The entire microarray data set is available at the EMBL-EBI ArrayExpress site under the reference E-MTAB-1956.

\section{Real-Time RT-PCR}

Validation of the microarray data was done by quantitative real-time PCR (qRT-PCR) for a selection of deregulated genes of interest on individual placentas from a separate cohort of normal placentas $(n$ $=21)$, placentas with IUGR $(n=26)$, with pre-eclampsia $(n=9)$, with pre-eclampsia and IUGR $(n=6)$ was used. cDNA synthesis was performed using the MMLV cDNA or the SuperScript II synthesis kits (Invitrogen) from $2 \mu \mathrm{g}$ of RNA, previously treated with DNase I. Primers were designed using the PRIMER3 software (Whitehead Institute for Biomedical Research, Cambridge, MA). The list, sequences, and conditions of use of the primers are in Supplementary Table S2 online. Real-time PCR was performed using the LightCycler 480, the corresponding LC480 SYBRGreen Master kit and 96-well plates (Roche, Madison, WI). Conditions were as follows: $95^{\circ} \mathrm{C}$ for $5 \mathrm{~min}$, and 40 cycles of three temperature steps $\left(95^{\circ} \mathrm{C}\right.$ for $10 \mathrm{~s}, 55^{\circ} \mathrm{C}$ for $10 \mathrm{~s}$, and $72{ }^{\circ} \mathrm{C}$ for $10 \mathrm{~s}$ ). Finally, samples were submitted to a progressive temperature ramping resulting in a melting curve, validating the specificity of the amplification. Amplification products were also checked by agarose gel electrophoresis and sequencing. The threshold cycle numbers $\left(C_{t}\right)$ were collected using the LightCycler 480 software (Roche) in the exponential phase of the amplification. The C's was normalized by the $C_{t}$ values obtained for the succinate dehydrogenase subunit A and TATA box binding protein, which have been shown previously to be stable and highly expressed in the human placenta (38). Succinate dehydrogenase subunit A and TATA box binding protein, which were used for normalization did not differ between the experimental groups in our study. Experiments were conducted in triplicates. As the data were normally distributed, we did ANOVA with a post hoc test (Student-Newman-Keuls).

\section{Microarray Analysis}

Global analysis was first made according to $P$ value. Nonsupervised clustering analyses were performed using the Array Mining software (School of Computer Science, Nottingham University, UK) (39) and DAVID database (Database for Annotation and Visualization and Integrated Discovery, Laboratory of Immunopathogenesis and Bioinformatics, Frederick, MD). Heatmaps were generated from the most significantly modified genes based on the $P$ value using Array Mining software. Pathway analysis was carried out using Array Mining software and DAVID database. Secondly, the tables of genes modified more than 1.5 -fold with a $P<0.05$ were submitted as text files with the level of induction/repression. This made it possible to generate pathways with a $P<0.01$ threshold for significance in the gene clustering. Promoters of the forty most induced and repressed genes compared to a panel of 40 nonmodified genes were obtained using the Genomatix software and database (Munich, Germany), selecting the gold promoters where possible and silver ones alternatively. Predicted transcription factor binding sites were identified and counted. A statistical analysis was performed by comparing the induced and repressed genes to the control group using a Student $t$-test corrected for multiple testing.

\section{Statistical Analysis}

The induction ratios were calculated from the difference between the raw data of fluorescence $\log _{2}$ transformed. Correlation tests were performed with these ratios using Microsoft Office Excel and GraphPrism. Values of $P<0.05$ were considered significant. 


\section{SUPPLEMENTARY MATERIAL}

Supplementary material is linked to the online version of the paper at http:// www.nature.com/pr

\section{ACKNOWLEDGMENTS}

We are grateful to all participating patients, as well as to the Centre $d^{\prime}$ Investigation Clinique en Périnatalogie of the Port Royal maternity for their expertise and help.

\section{STATEMENT OF FINANCIAL SUPPORT}

The authors have no support or funding to report.

Disclosures: The authors have declared that no competing interests exist.

\section{REFERENCES}

1. Charkaluk ML, Marchand-Martin L, Ego A, et al.; Epipage Study Group. The influence of fetal growth reference standards on assessment of cognitive and academic outcomes of very preterm children. J Pediatr 2012;161:1053-8.

2. American College of Obstetricians and Gynecologists. ACOG Practice bulletin no. 134: fetal growth restriction. Obstet Gynecol 2013;121:1122-33.

3. Zeitlin J, El Ayoubi M, Jarreau PH, et al.; MOSAIC Research Group. Impact of fetal growth restriction on mortality and morbidity in a very preterm birth cohort. J Pediatr 2010;157:733-9.e1.

4. McIntire DD, Bloom SL, Casey BM, Leveno KJ. Birth weight in relation to morbidity and mortality among newborn infants. N Engl J Med 1999;340:1234-8.

5. Damodaram M, Story L, Kulinskaya E, Rutherford M, Kumar S. Early adverse perinatal complications in preterm growth-restricted fetuses. Aust N Z J Obstet Gynaecol 2011;51:204-9.

6. Flamant C, Gascoin G. [Short-term outcome and small for gestational age newborn management]. J Gynecol Obstet Biol Reprod (Paris) 2013;42: 985-95.

7. Myatt L. Placental adaptive responses and fetal programming. J Physiol 2006;572(Pt 1):25-30.

8. Barker DJ, Winter PD, Osmond C, Margetts B, Simmonds SJ. Weight in infancy and death from ischaemic heart disease. Lancet 1989;2:577-80.

9. Gascoin G, Flamant C. [Long-term outcome in context of intra uterine growth restriction and/or small for gestational age newborns]. J Gynecol Obstet Biol Reprod (Paris) 2013;42:911-20.

10. Buffat C, Mondon F, Rigourd V, et al. A hierarchical analysis of transcriptome alterations in intrauterine growth restriction (IUGR) reveals common pathophysiological pathways in mammals. J Pathol 2007;213: $337-46$.

11. Vaiman D, Calicchio R, Miralles F. Landscape of transcriptional deregulations in the preeclamptic placenta. PLoS One 2013;8:e65498.

12. Moslehi R, Mills JL, Signore C, Kumar A, Ambroggio X, Dzutsev A. Integrative transcriptome analysis reveals dysregulation of canonical cancer molecular pathways in placenta leading to preeclampsia. Sci Rep 2013;3:2407.

13. Winn VD, Haimov-Kochman R, Paquet AC, et al. Gene expression profiling of the human maternal-fetal interface reveals dramatic changes between midgestation and term. Endocrinology 2007;148:1059-79.

14. Nishizawa H, Ota S, Suzuki M, et al. Comparative gene expression profiling of placentas from patients with severe pre-eclampsia and unexplained fetal growth restriction. Reprod Biol Endocrinol 2011;9:107.

15. Struwe E, Berzl G, Schild R, et al. Microarray analysis of placental tissue in intrauterine growth restriction. Clin Endocrinol (Oxf) 2010;72:241-7.

16. Kim J, Zhao K, Jiang P, et al. Transcriptome landscape of the human placenta. BMC Genomics 2012;13:115.

17. Shi Z, Long W, Zhao C, Guo X, Shen R, Ding H. Comparative proteomics analysis suggests that placental mitochondria are involved in the development of pre-eclampsia. PLoS One 2013;8:e64351.

18. Mandò C, De Palma C, Stampalija T, et al. Placental mitochondrial content and function in intrauterine growth restriction and preeclampsia. Am J Physiol Endocrinol Metab 2014;306:E404-13.
19. Edery P, Marcaillou C, Sahbatou M, et al. Association of TALS developmental disorder with defect in minor splicing component U4atac snRNA. Science 2011;332:240-3.

20. Bajoria R, Sooranna SR, Ward BS, Chatterjee R. Prospective function of placental leptin at maternal-fetal interface. Placenta 2002;23:103-15.

21. Gambino YP, Maymó JL, Pérez Pérez A, Calvo JC, Sánchez-Margalet V, Varone CL. Elsevier Trophoblast Research Award lecture: Molecular mechanisms underlying estrogen functions in trophoblastic cells-focus on leptin expression. Placenta 2012;33 Suppl:S63-70.

22. Maymó JL, Pérez Pérez A, Gambino Y, Calvo JC, Sánchez-Margalet V, Varone CL. Review: Leptin gene expression in the placenta-regulation of a key hormone in trophoblast proliferation and survival. Placenta 2011;32:Suppl 2:S146-53.

23. Dötsch J, Nüsken KD, Knerr I, Kirschbaum M, Repp R, Rascher W. Leptin and neuropeptide $\mathrm{Y}$ gene expression in human placenta: ontogeny and evidence for similarities to hypothalamic regulation. J Clin Endocrinol Metab 1999;84:2755-8.

24. McCarthy JF, Misra DN, Roberts JM. Maternal plasma leptin is increased in preeclampsia and positively correlates with fetal cord concentration. Am J Obstet Gynecol 1999;180(3 Pt 1):731-6.

25. Mise $\mathrm{H}$, Yura $\mathrm{S}$, Itoh $\mathrm{H}$, et al. The relationship between maternal plasma leptin levels and fetal growth restriction. Endocr J 2007;54:945-51.

26. Breier BH, Vickers MH, Ikenasio BA, Chan KY, Wong WP. Fetal programming of appetite and obesity. Mol Cell Endocrinol 2001;185:73-9.

27. Lee PD, Giudice LC, Conover CA, Powell DR. Insulin-like growth factor binding protein-1: recent findings and new directions. Proc Soc Exp Biol Med 1997;216:319-57.

28. Leu JI, Crissey MA, Taub R. Massive hepatic apoptosis associated with TGF-betal activation after Fas ligand treatment of IGF binding protein1-deficient mice. J Clin Invest 2003;111:129-39.

29. Reinehr T, Kleber M, Toschke AM, Woelfle J, Roth CL. Longitudinal association between IGFBP-1 levels and parameters of the metabolic syndrome in obese children before and after weight loss. Int J Pediatr Obes 2011;6:236-43.

30. Chan TF, Tsai YC, Wu CH, Lee CH, Wang SH, Su JH. The positive correlation between cord serum retinol-binding protein 4 concentrations and fetal growth. Gynecol Obstet Invest 2011;72:98-102.

31. Miles JL, Huber K, Thompson NM, Davison M, Breier BH. Moderate daily exercise activates metabolic flexibility to prevent prenatally induced obesity. Endocrinology 2009;150:179-86.

32. Meisinger C, Rückert IM, Rathmann W, et al. Retinol-binding protein 4 is associated with prediabetes in adults from the general population: the Cooperative Health Research in the Region of Augsburg (KORA) F4 Study. Diabetes Care 2011;34:1648-50.

33. Rhie YJ, Choi BM, Eun SH, Son CS, Park SH, Lee KH. Association of serum retinol binding protein 4 with adiposity and pubertal development in Korean children and adolescents. J Korean Med Sci 2011;26:797-802.

34. Mamelle $\mathrm{N}$, Boniol $\mathrm{M}$, Rivière $\mathrm{O}$, et al. Identification of newborns with Fetal Growth Restriction (FGR) in weight and/or length based on constitutional growth potential. Eur J Pediatr 2006;165:717-25.

35. Gascoin-Lachambre G, Buffat C, Rebourcet R, et al. Cullins in human intra-uterine growth restriction: expressional and epigenetic alterations. Placenta 2010;31:151-7.

36. Barbaux S, Gascoin-Lachambre G, Buffat C, et al. A genome-wide approach reveals novel imprinted genes expressed in the human placenta. Epigenetics 2012;7:1079-90.

37. Vaiman D, Gascoin-Lachambre G, Boubred F, et al. The intensity of IUGRinduced transcriptome deregulations is inversely correlated with the onset of organ function in a rat model. PLoS One 2011;6:e21222.

38. Meller M, Vadachkoria S, Luthy DA, Williams MA. Evaluation of housekeeping genes in placental comparative expression studies. Placenta 2005;26:601-7.

39. Glaab E, Garibaldi JM, Krasnogor N. ArrayMining: a modular webapplication for microarray analysis combining ensemble and consensus methods with cross-study normalization. BMC Bioinformatics 2009;10:358. 